UDC 811.133.1:81'373.611

DOI https://doi.org/10.32838/2663-6069/2020.3-1/23

Kosovych $\boldsymbol{O} . \boldsymbol{V}$.

Ternopil Volodymyr Hnatiuk National Pedagogical University

\title{
COMPARATIVE ANALYSIS OF GENDER MODELS OF SPEECH ACTIVITY IN ENGLISH AND UKRAINIAN LANGUAGES
}

This article is devoted to the peculiarities of men's and women's speech in different communicative situations in Ukrainian and English linguo-cultures. We tried to analyze similarities and differences in English and Ukrainian languages from the point of view of gender characteristic features. We came to the conclusion that from the point of view of the social theory of gender roles, differences in the behavior of men and women are associated with the roles that society ascribes to them. To meet these expectations, individuals of both sexes learn appropriate patterns of communicative behavior and behave in accordance with these expectations. The language has fixed a patriarchal attitude: stereotypes are firmly entrenched in it, according to which a woman has many vices, therefore, comparison with her man always carries a negative connotation: talkative, curious, flirtatious, narcissistic, capricious, hysterical as a woman, women's logic; a comparison with a man only adorns a woman: a man's mind, a man's grip, a man's character. Therefore, in those cases when it is necessary to characterize negatively the referent with male characteristics, they resort to the transfer of evaluation attributes stereotypically attributed to women. If the evaluative characteristics of the male referent are transferred to the female referent, then the emotional rating goes from neutral to positive. Thus, the linguistic aspect of gender is an actual direction in linguistics. Linguistic research of the ways of expression of gender in language at all levels, the relationship of the expression of sex and attributing to it a rating, description of gender stereotypes allow us to describe not only anthropocentric system of language, but also to explore the possibilities and boundaries of its subsystems related to masculinity and femininity as two hypostases of the human being.

Key words: gender, English language, Ukrainian language, linguo-culture, linguistics, gender stereotypes.

Introduction. For several decades, the issue of differences in the communicative behavior of men and women is a topic of linguistic research. In the 70-ies scientists linguists noted that there are certain gender differences in communication behavior. Despite the inconsistency of the obtained results, scientists were unitedinonething:men and women mostlyspeak the same language but use it differently, due to the specificity of gender socialization, different objectives and interests of both sexes. Recent studies have shown that language of women and language of men as a constant formation does not exist. "The matter is only about the typical features of male and female speech, the detected trends in the use of language by men and women" [5, p. 133]. This view is held by both domestic and western linguists. Modern researchers are interested in identifying gender stereotypes and the definition of their specificity. Gender stereotypes are seen as "a special case of stereotype knowledge on persons of different sexes, attributing them certain characteristics. Gender stereotypes fix in the language the notions of masculinity and femininity and their associated patterns of behavior of individuals" [6, p. 18].
Literature overview. The verbal features of communicative behavior of men and women, who are most often the cause of misunderstandings or conflicts between them, and analysis of verbal communication, the use of certain linguistic means and the specific style of communicative behavior became the subject of research of domestic and foreign scientists (A. Kyrylina, Yu. Melnyk, N. Myronova, J. Butler, D. Tannen, S. Tromel-Plotz). A significant contribution to the popularity and continuing relevance of gender in linguistics was made by $\mathrm{J}$. Grimm when referring to the genus as a language category, thus proving the relationship of language and reality. Along with the comparison of gender and grammar the phenomenon of gender is also examined in relation to rhetoric as one of the sections in linguistics. For example, one of the first impulses in the research of German scientists in this direction "Theses of feminist rhetoric" of R. Venske can be considered, published in the middle of 80-ies.

The aim and objectives of the study. The purpose of this approach is to explain and describe how the presence of people of different sexes manifests itself 
in the language, as well as what qualities and ratings are attributed to women and men, in which thematic areas of the linguistic picture of the world they are most common and how gender stereotypes work.

Results of the study and their discussion. In the course of time, the sex of a person has turned from a biological characteristic into a socio-psychological characteristic. Thus, the concept of "gender", which means a set of cultural and social norms prescribed by society for people to fulfill depending on their biological gender" [1].

The concept of "gender" has already gone beyond the scope of grammar. This phenomenon is considered as a discursive, sociocultural and psycholinguistic phenomenon.

For the first time, the gender factor regarding language appeared in antiquity in comprehending the grammatical category of the gende. For a long time, the only hypothesis about the causes and functioning of the gender category in the language was symbolicsemantic one, based on the correlation of the biological category sexus and grammatical genus. Proponents of this hypothesis believed that the grammatical gender arose due to the natural reality - the existence of people of different sexes (I. Herder, V. Humboldt, J. Grimm); moreover, in order to explain the extralinguistic motivation of the category of the genus, scientists used non-linguistic experience.

At the beginning of the last century, the theme "Language and Gender" attracted the attention of F. Mautner and O. Jespersen. F. Mautner substantiated gender differences in language from the point of view of social and historical reasons. According to F. Mautner, the creative use of language is a male prerogative, and women can only learn the language created by men. O. Jespersen believed that women are conservative in using the language, as illustrated by the example of emigrant communities, where the native language is preserved and at the same time a new one is adopted. At the same time, men learn a new language much faster. But it was not taken into account that the study of a foreign language by men was dictated by the need to work and speak a new language. Women in a home environment did not have such a need [4].

In the early $70 \mathrm{~s}$, gender studies from the point of view of language received a huge impetus, thanks to the emerged female movement in the United States and Germany, as a result of which a peculiar direction was formed in linguistics, which was called feminist linguistics.

Gender relations are an important aspect of social organization. They express its systemic characteristics and structure relations between speaking subjects. The main theoretical and methodological provisions of gender theory are based on four interconnected components: normative statements, cultural symbols, which set directions for various interpretations of such symbols and are expressed in scientific, religious, legal or political doctrines; organizations and social institutions; self-identity. Gender relations are recorded in the language as culturally determined stereotypes, leaving a certain imprint on behavior, including speech, personality and all the processes of its linguistic socialization [4].

In the $80 \mathrm{~s}$, a more balanced understanding of tender emerged as a problem not so much an explication of female history and psychology as a problem of a comprehensive study of masculinity and femininity of cultural and social expectations associated with them. At the end of the last century, a direction arose that studied only masculinity, and the understanding came that masculinity has various manifestations in any society; and the most important of these areas came to be called dominant masculinity.

Studying the structure of language associated with gender today, scientists proceed from its cultural and social conditioning, which is considered in the field of linguo-culturology. According to E. Zemskaya [5], this science is the latest molecular combination of cultural studies and linguistics and gives us the opportunity to study the interaction of language and culture in the context of gender issues from a new perspective. Man is the link between language and culture. He is a speech, linguistic and communicative person, whose formation takes place in the process of socialization. One cannot disagree with the opinion of R. Lakoff that gender is a sociocultural construct, therefore, the study of its specificity is necessary in the framework of the linguoculturological aspect of a particular discourse.

The most intensive study of the gender category in linguistics is fixed at the end of the $\mathrm{XX}$ - beginning of the XXI century. This is due to many factors, primarily the change in the scientific paradigm in the humanities under the influence of the postmodernism's philosophy. The knowledge of categorization processes from a new perspective, interest in a person's private life and subjective as a whole, the development of new personal concepts, including the theory of social constructivism, all this led to a rethinking of the scientific principles of the study of categories such as ethnicity, gender and age, considered before as biologically determined. With this approach, it became necessary 
to use a new terminology that more closely matches the methodological guidelines of scientists, and this was the reason for introducing the term gender into scientific circulation, which was intended to emphasize the nature of sex, formed and supported by society, its conventionality and institutionality. This approach, of course, contributed to the study of linguistic mechanisms of gender expression in language and communication [5].

Overcoming a straightforward interpretation of gender is today one of the most important conditions for studying various gender aspects of language and communication, and parameterization of masculinity and femininity from the standpoint of gender and cognitive linguistics should take into account the specifics of the implementation of gender stereotypes in the language.

Each linguistic culture is characterized by the presence of a gender picture of the world, including such a person's view of reality, when things and relationships are classified as binary oppositions, the elements of which can be associated with the feminine and masculine principles. The stereotype that is associated with the masculine principle is, first of all, "the formation of one's meaning in life, one's culture and society, and with the feminine one, reproduction and the sphere of nature. Women's social dynamics are significantly lower compared to men's one. However, over time, their role functions may change" [6].

Both the system (linguistic) and the communication level of the language have gender specifics. The system level includes various kinds of asymmetries, word-formation and semantic lacunae. As for the level of communication, this is the frequency of use of one form or another, the preference of the masses or individuals, determined by linguistic and cultural factors.

The mentioned directions did not succeed each other, but "moved» from one to another, and currently continue to coexist, in some cases competing with each other. From a different angle, they study the following groups of problems" [7]:

1. Language and gender reflection in it: vocabulary, nominative system, gender category, syntax and some similar objects. The purpose of this approach is to explain and describe how the presence of people of different sexes manifests itself in the language, as well as what qualities and ratings are attributed to women and men, in which thematic areas of the linguistic picture of the world they are most common and how gender stereotypes work.

2. Written and oral speech behavior of both men and women. In the course of the study of the linguistic marking of the gender attribute, we found that in speech behavior of woman is guided by "open social prestige", that is, on generally recognized norms of social and speech behavior, while a man gravitates to the so-called hidden prestige - to deviate from established norms and rules of communication. As a result, women tend to use euphemisms in their speech. They try to avoid elements of familiarity, nicknames, and invective vocabulary. A woman in her speech often uses specific nouns, and men abstract; men more often use verbs of active voice, but women use verbs of passive voice. This is due to a more active male lifestyle. At the same time, we found that with an increase in the level of education, differences in speech become less noticeable [5, p. 129]. If you analyze the English language, then one of the characteristic features of female speech is the use of evaluative adjectives. A man, if he uses evaluative adjectives, is rather one that defines parametric and quantitative relationships. According to L. Hirschman, a woman would rather use awful or pretty than very and so [8]. In women's speech, introduction words expressing a different degree of confidence, referring to one's own or someone else's opinion are much more often present. For example, probably, possibly, certainly, I think, I suppose; you see, to seem, to my mind. These words are usually at the beginning of a sentence. Women are much more likely than men to use the "You know" construct. More frequent use of units of affected vocabulary ("awfully pretty", "terribly nice" - terribly cute), various intensifiers, particles or exclamatory sentences ("What lovely earrings!") is associated with the tremendous emotionality of female speech. In the woman's speech, deeper hyperbolization is also found, and in addition, the frequency of using stylistic tropes is higher: "I'd just die" [8]. In men, the use of words with less emotional indexing and the uniformity of lexical techniques predominates when transmitting assessments or emotional characteristics. When analyzing the verbal behavior of the sexes, we have to pay attention to the syntactic language level. Due to the increased emotional level in women, they have a higher incidence of inverted and elliptical constructions. In English, women and men form their sentences in different ways, for example, in a man's speech you can often find a complex, confusing syntax. A man usually introduces one sentence into another, puts them into each other. Female syntax is a complex of words going in order, one after another. O. Jespersen calls this coordination, that is, hypotaxis is characteristic of men, and parataxis is characteristic of women [2]. 
Nevertheless, it should be remembered that there are no sharp boundaries between male and female speech in English. The noted features of male and female speech are defined as application trends. Very often, those or other phenomena found in the speech of both men and women are associated with the peculiarities of their character, mental state, profession, social role, but not with gender differences. Within the framework of the gender marking of the language, first of all, one should consider the lexical linguistic composition, since at the lexical level the gender characteristics of a particular language are more clearly manifested. Initially, it was only about androcentrism and the proof of its presence in the language and culture: the language is not only anthropocentric, but also androcentric, that is, it reflects the male perspective and is oriented towards representatives of the masculine gender. In any language you can find signs of androcentricity due to the peculiarities of the development of mankind from a historical point of view. But the degree of its intensity and severity can vary from one culture to another and, therefore, from one language to another [2]. For example, in English, the same lexeme (man) is used to refer to human being, person and man. If we consider the manifestation of femininity and masculinity in the Ukrainian language, we can see that - although the Ukrainian language also has androcentrism - it manifests itself not so clearly. The derivative possibilities of the word man are much wider, than of Ukrainian lexeme man. If we analyze the lexicographic works, we can see that the word man has a significantly larger number of related combinations than the Ukrainian word man - manlike, manliness, manhood. The gendermarked vocabulary includes those lexical units in which the " gender» component is implemented in more contrasting ways. The gender marking of a language is manifested through:

1. Personal pronouns that construct gender in the language, carrying it in the most natural way - speech or in any type of conversation. Without a gender marking in a subjective way (pronouns mark gender opposition only in the third person, and are not carriers of gender in themselves in other persons), they can support the concept of gender, performing at the same time another function.

2. The use of lexemes correlated with men or women with the help of their internal form: father, mother, daughter, son, bride, groom, king, queen; father, mother, daughter, son, groom, bride, king, queen.

3 . The use of words and phrases having a huge number of units with a "gender component" indicating the gender of the referent:
1. In English, such words or phrases include the following components: man, woman, boy, girl (sex-specific words): alderman, manservant, manatarms, gentlemanlike; woman's grace, womanliness, girlhood, wifely.

2. Phraseological units that correspond to a man or woman: Achilles' heel, drunk as a lord (drunk as a shoemaker), doubting Thomas (Thomas unbeliever, skeptic), good Joe (good guy), wise as Solomon (sage); old wives' tales (gossip women, grandma's tales).

The analysis showed that in the majority of cases in Ukrainian, collocations that relate to female referents include feminine nouns, and collocations that relate to male referents, are masculine nouns: здоровий, як бик (healthy, like a bull); незграбний, як слон (clumsy, like an elephant); блазень (a pea jester); зла, як відьма (wicked like a witch); тендітна панночка (prim young lady). In contrast to English, the main role in gender marking in the Ukrainian language is played by the category of gender. In Ukrainian, the category of grammatical gender is widespread. Each noun (animate or inanimate) as part of its own seme, defining its grammatical essence, has the seme of gender, masculine, feminine or neuter. The category of the grammatical gender was previously once inherent in the nouns of the Old English period. The historical development of the morphology of the English language has led to the disappearance of the category of gender, which at this stage of the development of the language is devoid of morphological means of expression. It is worth mentioning such relationships in the system of nouns as actor-actress, poet-poetess, ambassador - ambassadress, widow - widower, sultan - sultana, count - countess, duke - duchess. This way of expressing female and male nominations occurs by translating a noun into a " female» form using suffixes (for example, -ess, - $a$, -trix). But these suffixes are not indicative of " gender» differences in the system of English nouns.

4. The words that surround the concepts of "man" and "woman". The main groups of such units are: a) external description: - man: handsome; excellent turn of shoulders and woman: beautiful, charming, cute, shapely figure; lovely figure; b) psychological qualities, behaviors: - man: rough-housing, to hide one's emotions, telling dirty jokes; composure, tactlessness, rudeness woman: nagging, crying, gossiping, capricious, blushing; talkativeness, shyness, tendency to tears; c) units that have only male or female referents because of an internal form that refers to the peculiarities of life of men and women:man: to serve in the army; protect the homeland - woman: 
bear children, to be pregnant; motherhood, pregnancy; d) non-verbal behavior. Gender differences that are reflected in non-verbal behavior have led to that individual gestures and even styles of non-verbal behavior began to be evaluated as female and male, regardless of the actual gender of the executor. For example, a typical male gesture is the "rub one's hands [with pleasure]" gesture, with which the gesticulator conveys his positive expectations.

Another difference in the styles of speech behavior is that men prefer to speak directly, and the statements of women have an inherent indirectness. According to D. Tannen, "women tend to express their desires not specifically, but using a leading question in order to find out what other participants in the communication might like. They are used to taking into account the interests of the partner and formulating statements openly, with the goal of making a joint decision" [13]. Since men express their needs more directly, they are often unable to recognize the meta-message in the expression of women.

In studies of foreign linguists, other gender features of communicative behavior are also highlighted. For example, with regard to the course of the conversation, women demonstrate a desire to follow the topic of discussion, to agree with a partner. Men, on the contrary, ignore the topic of their partner, refer to other information and constantly use their position as a starting point [9]. The male style of communicative behavior is the exact opposite of the female style. In the opinion of K. Schmidt the features of the male style of speech include: orientation to non-cooperative behavior instead of cooperative one; long monologues instead of the speaker changing frequently; the presentation of one's own knowledge turns out to be more substantial than the elaboration and development of a common theme - each puts individual thematic accents, not particularly agreeing with previous statements; dominant behavior; frequent interruptions of the interlocutor; loud manner of conversation; repetition and statement of topics [10, p. 73-90].

As the results of research in the field of gender linguistics show, differences between male and female communicative behavior are found at all language levels. Feminist advocates speak of various "language registers" in this regard. They can be reduced to the following points: 1 . Women more often than men choose formulations that soften their statements. On the one hand, this is due to the use of diminutive forms, on the other hand, due to the connecting elements at the beginning or end of the sentence. 2. Women willingly give men the opportunity to choose a topic of conversation. Therefore, it is not surprising that in mixed groups, topics initiated by men dominate the conversation. Women often support and develop them, while topics initiated by women often do not resonate with men and are soon interrupted. 3. Women use vulgar expressions to a lesser extent than men. They swear less often and at the same time choose harmless words. 4. Women have a different lexical vocabulary than men. However, in traditionally female topics of conversation, such as housework, parenting, as well as fashion, their expressions are more accurate than in men. 5. Women are more likely to interrupt themselves than men. They are more silent and formulate their statements in interrogative form. 6. Finally, women more often than men agree with the arguments of the interlocutor. Depending on the situation, it can also happen that men use the "female" language, and women use the "male" language register. This can take place, first of all, in communicative situations, where there is strong pressure from the authorities. So when talking with the boss, the "female" register is most likely used, and with the subordinate - "male". In conclusion, it is worth saying that the listed differences between the communicative behavior of men and women are the main typical trends, and there are enough exceptions. From the point of view of the social theory of gender roles, differences in the behavior of men and women are associated with the roles that society ascribes to them. To meet these expectations, individuals of both sexes learn appropriate patterns of communicative behavior and behave in accordance with these expectations.

Conclusions. Thus, we can conclude that the language has fixed a patriarchal attitude: stereotypes are firmly entrenched in it, according to which a woman has many vices, therefore, comparison with her man always carries a negative connotation: talkative, curious, flirtatious, narcissistic, capricious, hysterical as a woman, women's logic; a comparison with a man only adorns a woman: a man's mind, a man's grip, a man's character. Therefore, in those cases when it is necessary to characterize negatively the referent with male characteristics, they resort to the transfer of evaluation attributes stereotypically attributed to women. If the evaluative characteristics of the male referent are transferred to the female referent, then the emotional rating goes from neutral to positive [6]. Thus, the linguistic aspect of gender is an actual direction in linguistics. Linguistic research of the ways of expression of gender in language at all levels, the relationship of the expression of sex and attributing to it a rating, description of gender stereotypes allow us to describe not only anthropocentric system of language, but also to explore the possibilities and boundaries of its subsystems related to masculinity and femininity as two hypostases of the human being. 


\section{References:}

1. Горбунова М. Ю. Языковое выражение этнической и гендерной предвзятости в английском и русском языках: лингвопрагматический аспект : автореф. дис. ... канд. филол. наук. Краснодар, 2008. 22 с.

2. Гречушникова Т. В. Загадки гендерной идентичности в немецкоязычной женской прозе конца XX века. Женщины. История. Общество. Тверь : Тверск. областное книжно-журнальное изд-во, 1999. Вып. 2. С. 158-259.

3. Дамадаева А. С. Психологические аспекты изучения гендерных стереотипов. Вестник интегративной психологии. Часть IV. М., 2010. Вып. 8. С. 23-30.

4. Витлицкая Е. Я. Лингвистическая репрезентация гендерных стереотипов в рекламе (на материале англоязычных и русскоязычных текстов) : автореф. дис. ... канд. филол. наук. Волгоград, 2005. 19 с.

5. Земская Е. А. Особенности мужской и женской речи. Русский язык в его функиионировании. Коммуникативно-прагматический аспект. Москва, 1993. С. 90-136.

6. Кирилина А. В. О применении понятия « гендер» в русскоязычном лингвистическом основании. Филологические науки. 2000. № 3. С. 18-27.

7. Кирилина А. В. Мужская и женская речь. Словарь гендерных терминов. Москва : Информация XXI век, 2002. C. 151-154.

8. Eubanks S. Unterschiede im Gesprächsverhalten von Männern und Frauen. Eubanks. FrauenspracheMännersprache. Ein Arbeitsbuch zur geschlechtsspezifischen Sprachverwendung. Frankfurt am Main : Moritz Diesterweg GmbH \& Co Verlag. 1981. S. 32-35.

9. Lenz I. Fühlen, Einfühlen und weibliche Sprache. Frauensprache - Männersprache. Ein Arbeitsbuch zur geschlechtsspezifischen Sprachverwendung. Frankfurt am Main : Moritz Diesterweg GmbH \& Co Verlag, 1981. S. 96-97.

10. Hertlein M. Frauen reden anders. Selbstbewusst und erfolgreich im Jobtalk. Hertlein. Rowohlt, 1990. $128 \mathrm{~S}$.

11. Pusch L. F. Das Deutsche als Männersprache. Linguistische Berichte. Frankfurt am Main: Suhrkamp Verlag, 1981. S. 59-74.

12. Schmidt C. Dieser Emil immer destruktiv. Eine Untersuchung über weibliches und männliches Kommunikationsverhalten in studentischen Kleingruppen. Die Geschlechter im Gespräch. Stuttgart: Metzler Verlag, 1992. S. 73-90.

13. Tannen D. Du kannst mich einfach nicht verstehen. Frankfurt am Main, Wien : Büchergilde Gutenberg, 1990. S. 342.

14. Trömel-Plötz, S. Feminismus und Linguistic. Feminismus. Inspektion einer Herrenkultur. Ein Handbuch. Frankfurt / Main, 1983. S. 3351.

15. Wald, R. Professionelle Interaktion und Kommunikation. Zur Sozialisierung junger Frauen und Männer in Verkaufsberufen. Frankfurt am Main : Westdeutscher Verlag, 1987. S. 58.

\section{КОСОВИч О. В. ПОРІВНЯЛЬНИЙ АНАЛІЗ ГЕНДЕРНИХ МОДЕЛЕЙ МОВЛЕННЕВОЇ ПОВЕДІНКИ В АНГЛІЙСЬКІЙ ТА УКРАЇНСЬКІЙ МОВАХ}

Ця стаття присвячена особливостям чоловічої й жіночої мови в різних комунікативних ситуачіях в украӥнській та англійській лінгвокультурах. Ми спробували проаналізувати подібності та відмінності в англійській та украйнській мовах з точки зору гендерних особливостей. Ми прийили до висновку, щзо з точки зору сочіальної теорї̈ гендерних ролей відмінності в поведінці чоловіків і жінок пов 'язані з ролями, які суспільство приписує їм. Для задоволення ичи очікувань особи обох статей засвоюють відповідні моделі комунікативної поведінки і ведуть себе відповідно до ичих очікувань. Мова зафіксувала патріархальні відносини: стереотипи міино засіли в ній, згідно з якими жінка має багато вад, тому порівняння з нею чоловіка завжси несе негативне забарвлення: балакучий, ијікавий, кокетливий, самозакоханий, примхливий, істеричний, як жінка, жіноча логіка; жінку ж порівняння з чоловіком тільки прикрашає: чоловічий розум, чоловіча хватка, чоловічий характер. Тому в тих випадках, коли необхідно негативно охарактеризувати референта з чоловічими ознаками, вдаються до перенесення оціночних ознак, які стереотипно приписують жінкам. Якщо ж очіночні ознаки референта-чоловіка переносяться на референта-жінку, то емочійна оиінка з нейтральної переходить в позитивну. Таким чином, лінгвістичний аспект гендеру є актуальним напрямком в лінгвістиці. Лінгвістичні дослідження способів вираження статі мовою на всіх ї̈ рівнях, взаємозв'язку вираження статі і приписування ій оиінки, опис гендерних стереотипів дозволяють проаналізувати не тільки антропоцентричну систему мови, але і вивчити можливості та межі ї̈ підсистем, пов'язаних із мужністю та жіночністю як двома іпостасями людського буття.

Ключові слова: гендер, англійська мова, украйнська мова, лінгвокультура, лінгвістика, гендерні стереотипи. 